Vol.2 No. 01Hal. $40-45$

April 2019

\title{
Cakupan Imunisasi Dasar Terhadap Standar Pelayanan Minimal di Puskesmas Desa Binjai Tahun 2018
}

\author{
dr. Alamsyah Lukito, M.Kes
}

Dosen Program Studi Kedokteran FK UISU

alamsyahlukito@fk.uisu.ac.id

\begin{abstract}
ABSTRAK
Penelitian ini bertujuan untuk mengetahui hasil cakupan imunisasi dasar terhadap standar pelayanan minimal di Puskesmas Desa Binjai tahun 2018. Untuk mengetahui distribusi frekuensi berdasarkan usia. Untuk mengetahui distribusi dan frekuensi berdasarkan jenis kelamin. Untuk mengidentifikasi pencapaian cakupan imunisasi dasar terhadap standar pelayanan minimal di Puskesmas Desa Binjai tahun 2018. hasil penelitian di Puskesmas Desa Binjai diperoleh data bahwa dari 94 orang, mayoritas respoden dengan jenis kelamin perempuan sebanyak 52 orang $(55,3 \%)$, serta minoritas responden dengan jenis kelamin laki-laki sebanyak 42 orang $(44.7 \%)$. cakupan imunisasi HB0 sebanyak 94 orang yaitu (100\%) dengan target pencapaian standar pelayanan minimal $80 \%$. Cakupan imunisasi BCG sebanyak 94 orang yaitu $(93,6 \%)$ dengan target pencapaian standar pelayanan minimal $90 \%$. Cakupan imunisasi DPT/HB1, DPT/HB2, DPT/HB3 sebanyak 94 orang yaitu $(100 \%)$ dengan target pencapaian standar pelayanan minimal $95 \%$. Cakupan imunisasi Polio 4 sebanyak 94 orang $(91,5 \%)$ cenderung lebih rendah dari cakupan imunisasi Polio 1, Polio 2, Polio 3 yaitu $100 \%$ dengan target pencapaian standar pelayanan minimal $95 \%$. Cakupan imunisasi campak sebanyak 94 orang yaitu $(95,7 \%)$ dengan target pencapaian standar pelayanan minimal $85 \%$. Dari hasil penelitian didapatkan kesimpulan bahwa cakupan imunisasi dasar lengkap pada bayi usia 12-24 bulan di Puskesmas Desa Binjai tahun 2018 telah mencapai target standar pelayanan minimal imunisasi yaitu $>90 \%$.
\end{abstract}

Kata Kunci : Imunisasi, Standar Pelayanan, Puskesmas, Distribusi Frekuensi

\begin{abstract}
This study aims to determine the results of basic immunization coverage on minimum service standards in the Binjai Village Health Center in 2018. To determine the frequency distribution based on age. To find out the distribution and frequency based on sex. To identify the achievement of basic immunization coverage for minimum service standards in Binjai Village Health Center in 2018, the results of research at Binjai Village Health Center showed that of 94 people, the majority of respondents with female gender were 52 people $(55.3 \%)$, and a minority of respondents with male sex as many as 42 people (44.7\%). HB0 immunization coverage of 94 people is $(100 \%)$ with a target of achieving a minimum standard of service of $80 \%$. BCG immunization coverage was 94 people $(93.6 \%)$ with a target of achieving a minimum service standard of 90\%. Immunization coverage of DPT / HB1, DPT / HB2, DPT / HB3 was 94 people namely (100\%) with a target of achieving a minimum service standard of $95 \%$. Polio 4 immunization coverage of 94 people (91.5\%) tended to be lower than Polio 1, Polio 2, Polio 3 immunization coverage of $100 \%$ with a target of achieving a minimum service standard of $95 \%$. Measles immunization coverage was 94 people, namely (95.7\%) with a target of achieving a minimum service standard of $85 \%$. From the results of the study it was concluded that the coverage of complete basic immunization in infants aged 12-24 months in the Binjai Village Health Center in 2018 had reached the minimum immunization service standard target of $>90 \%$.
\end{abstract}

Keywords : Immunization, Service Standards, Puskesmas, Frequency Distribution 
Lukito A : Cakupan Imunisasi Dasar Terhadap Standar Pelayanan Minimal di Puskesmas Desa Binjai Tahun 2018

\section{PENDAHULUAN}

\section{Latar Belakang}

Imunisasi merupakan salah satu upaya preventif untuk mencegah penyakit melalui pemberian kekebalan tubuh yang harus dilaksanakan secara terus-menerus, menyeluruh dan dilaksanakan sesuai standar sehingga mampu memberikan perlindungan kesehatan dan memutus mata rantai penularan (Kemenkes 2004). Imunisasi merupakan suatu upaya untuk menimbulkan atau meningkatkan kekebalan seseorang secara aktif terhadap suatu penyakit, sehingga apabila suatu saat terpajan penyakit tersebut, tidak akan sakit atau hanya sakit ringan (Buku Ajar Imunisasi, 2014). Imunisasi dibedakan menjadi dua golongan. Pertama, imunisasi yang harus diselesaikan sebelum usia 1 tahun. Kedua, imunisasi yang tidak boleh dilaksanakan pada usia kurang dari 1 tahun. Setelah anak diimunisasi, berarti diberikan kekebalan terhadap suatu penyakit tertentu. Anak kebal terhadap satu penyakit namun belum tentu kebal terhadap penyakit lainnya. Maka dari itu imunisasi harus diberikan secara lengkap (Yuniarto, 2010). Pelaksanaan imunisasi dapat mencegah 1-2 juta kematian setiap tahun akibat penyekit Difteri, Pertusis dan Tetanus. Namun pada tahun 2014 terdapat 18,7 juta bayi diseluruh dunia yang tidak mendapatkan imunisasi DPT3 dan lebih dari 60\% anak tersebar di Republik Demokrasi Kongo, Eutopia, India, Indonesia, Irak, Nigeria, Pakistan, Filipina, Uganda dan Afrika Selan (WHO 2015). Pada tahun 2015 cakupan Imunisasi Dasar Lengkap (IDL) adalah sebesar 86,8\% yang harus ditingkatkan menjadi 93\% di tahun 2019. Begitu pula dengan Universal Child Immunization (UCI) desa yang kini mencapai 82,9\% harus ditingkatkan menjadi $92 \%$ di tahun 2019. Oleh karena itu, dari 194 negara anggota WHO, 65 diantaranya memiliki cakupan imunisasi Difteri, Pertusis, Tetanus dibawah 90\% termasuk Indonesia (Pusat data dan informasi PERSI, 2015). Kebijakan imunisasi nasional menurut RPJMN-Kesehatan tahun 2015-2019 adalah tercapainya cakupan IDL sebesar 93\% pada usia 0-11 bulan dengan rincian tahun 2015 diharapkan tercapai 91\%, tahun 2016 sebesar 91,5\%, tahun 2017 sebesar 92\%, tahun 2018 sebesar 92,5\% dan tahun 2019 mencapai 93\%. (Kemenkes RI 2015). Salah satu hasil kegiatan yang ingin dicapai RJPM-Kesehatan periode 20152019 yaitu semua desa diharapkan telah mencapai UCI (Depkes RI, 2009). Namun dalam lima tahun terakhir program imunisasi di Indonesia tidak mengalami perkembangan yang signifikan. Hasil Riset Kesehatan Dasar 2018 Kementrian Kesehatan RI menunjukkan cakupan Imunisasi Dasar Lengkap (IDL) pada anak usia 12-23 bulan menurun dari 59,2\% di tahun 2013 menjadi 57,9\% di tahun 2018. Hal ini berarti dari 6 juta anak usia 12-23 bulan, hanya sekitar 2,5 juta yang telah mendapat imunisasi dasar lengkap. Sebaliknya, anak yang diimunisasi namun tidak lengkap meningkat dari 32,1\% menjadi 32,9\% dalam periode waktu yang sama (Ndoen, 2018). Berdasarkan Profil Kesehatan Sumatera Utara tahun 2014, cakupan IDL kabupaten/kota tertinggi di Sumatera Utara adalah Kabupaten Dairi yakni sebesar 106,92\% dan yang terendah adalah Kabupaten Nias Utara yakni sebesar 8,7\% (Dinkes Sumatera Utara, 2015). Sasaran imunisasi MR di Provinsi Sumatera Utara sebanyak 4.291.857 anak. Sampai dengan Oktober 2018 cakupan imunisasi dilaporkan mencapai 2.084 .997 anak $(48,60 \%)$. Kemenkes RI telah menetapkan target harian per Oktober 2018 sebesar 81,2\% maka dari 33 kabupaten/kota provinsi Sumatera Utara, baru 9 kabupaten yang telah mencapai target yaitu Toba Samosir $(101,90 \%)$, Samosir (100\%), Humbang Hasundutan $(98,15 \%)$, Dairi $(97,84 \%)$, Tapanuli Utara $(89,24 \%)$, Nias $(88,37 \%)$, Karo $(87,21 \%)$, Simalungun $(85,54 \%)$ dan Pematang Siantar (83,29\%). Puskesmas Desa Binjai di Kecamatan Medan Denai merupakan salah satu fasilitas kesehatan tingkat pertama (Puskesmas) yang juga menjalankan program Imunisasi. Peneliti memperoleh data cakupan standar pelayanan minimal imunsasi dasar di Puskesmas Binjai. 
Lukito A : Cakupan Imunisasi Dasar Terhadap Standar Pelayanan Minimal di Puskesmas Desa Binjai Tahun 2018

\section{Perumusan Masalah}

Berdasarkan uraian dalam latar belakang masalah, identifikasi masalah, maka dapat dirumuskan masalah penelitian yaitu sebagai berikut : Berdasarkan latar belakang diatas maka rumusan masalah dalam penelitian ini adalah, bagaimana hasil cakupan imunisasi dasar terhadap standar pelayanan minimal di Puskesmas Desa Binjai tahun 2018?

\section{Tujuan Penelitian}

\section{Tujuan Umum}

Adapun tujuan dari penelitian ini adalah untuk mengetahui hasil cakupan imunisasi dasar terhadap standar pelayanan minimal di Puskesmas Desa Binjai tahun 2018.

\section{Tujuan Khusus}

1. Untuk mengetahui distribusi frekuensi berdasarkan usia

2. Untuk mengetahui distribusi dan frekuensi berdasarkan jenis kelamin

3. Untuk mengidentifikasi pencapaian cakupan imunisasi dasar terhadap standar pelayanan minimal di Puskesmas Desa Binjai tahun 2018

\section{Manfaat Penelitian}

Manfaat yang diharapkan dalam penelitian ini adalah :

1. Bagi Puskesmas Desa Binjai

Sebagai bahan informasi dan penyuluhan dari Puskesmas kepada masyarakat dalam hal imunisasi dan sebagai bahan evaluasi puskesmas untuk terus meningkatkan cakupan imunisasi.

2. Bagi Institusi Pendidikan

Sebagai bahan referensi bagi peneliti selanjutnya yang ingin meniliti tentang imunisasi dengan variabel yang berbeda.

\section{METODE PENELITIAN}

Pengambilan sampel ini menggunakan tekhnik purposive sampling. Purposive sampling adalah salah satu teknik non probability sampling dimana peneliti menetapkan pengambilan sampel berdasarkan ciri-ciri khusus yang sesuai dengan tujuan penelitian sehingga diharapkan dapat menjawab masalah penelitian. (Sugiyono, 2012). Sampel yang digunakan dalam penelitian ini sesuai dengan kriteria inklusi dan berasal dari data yang telah diberikan oleh bagian administrasi di puskesmas tersebut. Desain yang digunakan dalam penelitian ini adalah desain studi deskriptif yang bertujuan untuk menggambarkan atau menganalisis suatu hasil penelitian tetapi tidak digunakan untuk membuat kesimpulan yang lebih luas (ugiono, 2009). Hasil analisisnya adalah tentang evaluasi cakupan imunisasi dasar di Puskesmas Desa Binjai, Kecamatan Medan Denai tahun 2018. Setelah seluruh data terkumpul akan dilakukan analisis melalui beberapa tahap. Pertama melakukan pemeriksaan data dan memastikan bahwa seluruh data telah terkumpul dan lengkap. Selanjutnya peneliti memasukkan data ke komputer untuk dilakukan pengolahan data secara komputerisasi. Setelah semua data terkumpul, maka dilakukan analisis data. Kemudian peneliti memasukkan data ke dalam komputer dan dilakukan pengolahan data secara komputerisasi. Selanjutnya memeriksa kembali data yang sudah dimasukkan kedalam komputer. Apabila ada kesalahan, maka dilakukan editing kembali. Analisis data menggunakan teknik analisis statistika univariat, dimana data yang diperoleh dari hasil pengumpulan data disajikan dalam bentuk tabel distribusi dan frekuensi. Analisis univariat dilakukan terhadap tiap variabel dari hasil penelitian. 
Lukito A : Cakupan Imunisasi Dasar Terhadap Standar Pelayanan Minimal di Puskesmas Desa Binjai Tahun 2018

\section{HASIL DAN PEMBAHASAN}

Hasil penelitian di Puskesmas Desa Binjai diperoleh data bahwa dari 94 orang, mayoritas respoden dengan jenis kelamin perempuan sebanyak 52 orang $(55,3 \%)$, serta minoritas responden dengan jenis kelamin laki-laki sebanyak 42 orang $(44.7 \%)$.

Distribusi Frekuensi Cakupan Program Imunisasi Dasar Terhadap Standar Pelayanan Minimal Imunisasi di Puskesmas Desa Binjai

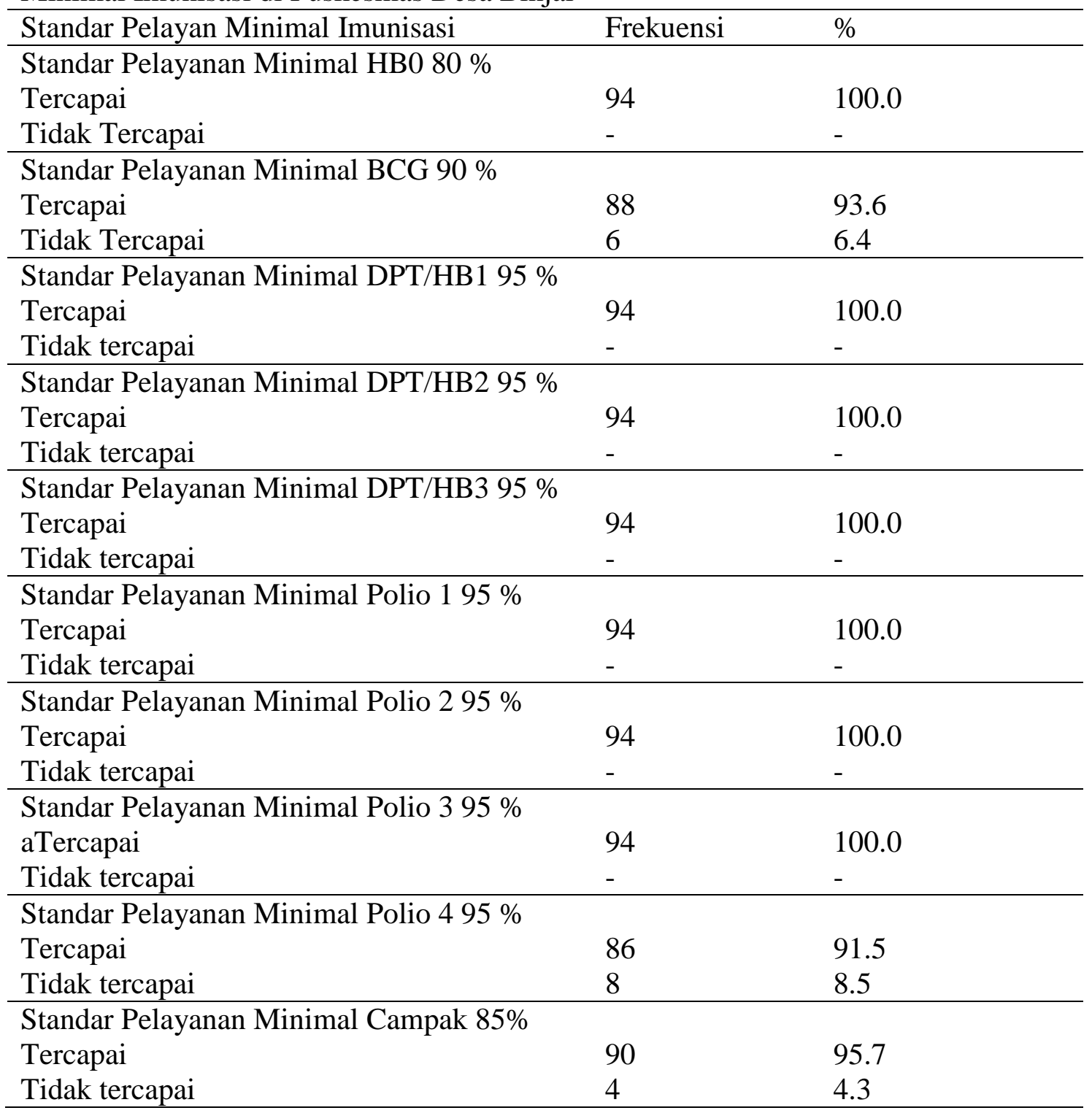

Berdasarkan tabel tersebut diperoleh bahwa cakupan imunisasi HB0 sebanyak 94 orang yaitu (100\%) dengan target pencapaian standar pelayanan minimal $80 \%$. Cakupan imunisasi BCG sebanyak 94 orang yaitu $(93,6 \%)$ dengan target pencapaian standar pelayanan minimal $90 \%$. Cakupan imunisasi DPT/HB1, DPT/HB2, DPT/HB3 sebanyak 94 orang yaitu (100\%) dengan target pencapaian standar pelayanan minimal $95 \%$. Cakupan imunisasi Polio 4 sebanyak 94 orang $(91,5 \%)$ cenderung lebih rendah dari cakupan imunisasi Polio 1, Polio 2, Polio 3 yaitu $100 \%$ dengan target pencapaian standar pelayanan minimal $95 \%$. Cakupan imunisasi campak sebanyak 94 orang yaitu $(95,7 \%)$ dengan target pencapaian standar pelayanan minimal $85 \%$. 
Lukito A : Cakupan Imunisasi Dasar Terhadap Standar Pelayanan Minimal di Puskesmas Desa Binjai Tahun 2018

Dari hasil penelitian didapatkan kesimpulan bahwa cakupan imunisasi dasar lengkap pada bayi usia 12-24 bulan di Puskesmas Desa Binjai tahun 2018 telah mencapai target standar pelayanan minimal imunisasi yaitu $>90 \%$. Menurut penelitian Tanjung dkk tahun 2015, pemberian ASI ekslusif berpengaruh terhadap kelengkapan imunisasi dasar bayi meskipun alasan yang tepat mengapa hal ini berkaitan belum diketahui. Sedangkan faktor lain seperti usia ibu, pekerjaan, pendidikan, cara lahir dan jumlah anak tidak mempengaruhi kelengkapan imunisasi dasar bayi. Penelitian ini sejalan dengan penelitian Kuswanto dkk tahun 2016 terkait pencapaian program imunisasi dasar lengkap bayi usia 12-24 bulan di Kabupaten Purworejo yang juga sudah cukup tinggi. Tidak jauh berbeda dengan SDKI tahun 2016. Hasil Survei Demografi dan Kesehatan Indonesia tahun 2017 mengungkapkan bahwa cakupan imunisasi dasar lengkap untuk anak usia 12-24 bulan di Indonesia mengalami peningkatan yakni sebesar 70\% di tahun 2017 dibandingkan 66\% di tahun 2012. Dari data tersebut dapat dilihat sejauh mana pencapaian berbagai program seperti imunisasi dan menjadi motivasi berbagai upaya untuk menigkatkan cakupan. (SDKI, 2017). Program Imunisasi Indonesia sudah mencapai predikat UCI yang merupakan suatu tahap dimana cakupan imunisasi di daerah tersebut sudah mencapai $80 \%$. Selanjutnya Indonesia harus berupaya dan memiliki target untuk mewujudkan $100 \%$ UCI desa/kelurahan yang berarti cakupan imunisasi di daerah tersebut telah mencapai $100 \%$. Tidak terdapat perbedaan cakupan menurut jenis kelamin, namun terdapat perbedaan menurut daerah. Masih terdapat juga bayi yang tidak diimunisasi di Puskesmas Desa Binjai. Hal ini dapat menghambat upaya pemerintah dalam mencapai target imunisasi di desa/kelurahan. Dari uraian diatas didapatkan bahwa program imunisasi dasar di Puskesmas Desa Binjai tahun 2018 telah mencapai Standar Pelayanan Minimal (SPM) sesuai dengan yang sudah ditetapkan oleh pemerintah

\section{DAFTAR PUSTAKA}

Badan Pusat Statistik. 2012. Survei Demografi dan Kesehatan Indonesia (SDKI). Jakarta: Badan Pusat Statistik.

Depkes RI. 2009. Profil Kesehatan Indonesia Tahun 2009. Jakarta: Departemen Kesehatan RI.

Dinkes. 2015. Profil Kesehatan Sumatera Utara. Medan: Dinas Kesehatan Sumatera Utara. Gupte, S. (2004). Panduan perawatan anak. Jakarta : Pustaka Populer Obor.

Kuswanto, Hardjo. 2016. Gambaran Tingkat Pengetahuan Ibu terhadap Imunisasi. Medan: FK USU

Hidayat, A.A. (2009). Ilmu Kesehatan Anak. Jakarta : Salemba Medika.

IDAI. 2018. Seputar Pekan Imunisasi Dunia. Dalam http://www.idai.or.id/artikel/klinik/imunisasi/seputar-pekan-imunisasi-dunia-2018 diakses tanggal 25 April 2019.

IZN. 2017. Indonesia Termasuk Negara yang Tak Capai Target Imunisasi. Pusat data dan Informasi

PERSI

dalam http://www.pdpersi.co.id/content/news.php?mid=5\&nid=1930\&catid=23 diakses tanggal 26 April 2019. 
Lukito A : Cakupan Imunisasi Dasar Terhadap Standar Pelayanan Minimal di Puskesmas Desa Binjai Tahun 2018

Kemenkes RI, (2013). Profil Kesehatan Indonesia Tahun 2013, Jakarta: Kementerian Kesehatan RI.

Kemenkes RI, GAVI, (2014). Buku Ajar Imunisasi. Jakarta: Kementrian Kesehatan RI

Kemenkes. 2017. Profil Kesehatan Indonesia. Jakarta: Kementrian Kesehatan Republik Indonesia.

Marimbi, H., (2010). Tumbuh Kembang, Status Gizi, dan Imunisasi Dasar Pada Balita. Yogyakarta: Nuha Medika.

Maryunani, A., (2010). Ilmu Kesehatan Anak Dalam Kebidanan. Jakarta: CV. Trans Info Media, 207-223.

Muslihatun, W.N. (2010). Asuhan neonatus bayi dan balita. Yokyakarta : Fitramaya.

Ndoen, Ermi. 2017. Krisis Kepercayaan Penyebab Cakupan Imunisasi Anak Indonesia Turun 5 Tahun Terakhir. The Conversation.

Unicef Indonesia. 2012. Imunisasi untuk Semua Anak, dalam https://www.unicef.org/indonesia/id/reallives_20475.htm diakses tanggal 26 April 2019.

WHO. 2015. Immunization. Geneva: World Health Organization

Yuniarto, Ponco. 2015. Pentingnya Imunisasi bagi Anak. Jurnal Litbang Pengendalian Penyakti Bersumber Binatang Banjarnegara BALABA. Vol 6 no. 01, dalam http://ejournal.litbang.depkes.go.id/index.php/blb/article/view/1721/3241 